\title{
Current Technologies for Fixation of Biological Material for mmmunohistochemical Analysis (Review)
}

Dol. 10.17691/stm2018,10.2.19

Received July 12, 2017

(c)

1.P. Grigorev, PhD, Senior Researcher, Laboratory of Functional Morphology of Central

and Peripheral Nervous System, Department of General and Special Morphology;

D.E. Korzhevskii, MD, PhD, Professor of the Russian Academy of Sciences, Head of the Laboratory

of Functional Morphology of Central and Peripheral Nervous System, Department of General

and Special Morphology

Institute of Experimental Medicine, 12 Akademika Pavlova St., Saint Petersburg, 197376, Russia

\begin{abstract}
Based on their own experience and published reports the authors provide an insight into the existing methods of fixation of biological material used in immunohistochemistry. The first quality of an immunohistochemical fixative should be its ability to preserve the tissue structure so that the antigenic properties of macromolecules are minimally affected. Considering this point, the review analyzes the applicability of commonly used fixatives to immunohistochemical staining; among those, aldehydes (formaldehyde, glutaraldehyde, glyoxal), dehydrating (coagulating) agents (ethanol, methanol, acetone), combined fixation solutions (Bouin's solution, Carnoy's solution, methacarn, etc.), as well as the recent zinc-containing fixatives and commercial products. Most of these fixatives inevitably change the tertiary and quaternary structure of many proteins; therefore, the detection of these proteins by immunohistochemistry requires an additional procedure of unmasking the epitopes using proteolytic enzymes or elevated temperatures. When compared for the preservation of antigenic structures, a high quality of the novel zinc-containing fixative - zinc-ethanol-formaldehyde - was noted. It has been concluded that none of the fixatives known to date has such a combination of properties that allow obtaining high-quality histological preparations and, at the same time, allows for detecting of any antigens in the stained tissue.
\end{abstract}

Key words: fixation of biological material; immunohistochemistry; formalin; ethanol; glutaraldehyde; zinc salts; zinc-ethanolformaldehyde; heat induced epitope retrieval.

\section{Introduction}

Immunohistochemistry is a unique method for studying and analyzing biological objects; it shows the localization of various molecules in the tissue at different levels - in cells, subcellular structures, and the intercellular space. To obtain results of biological or medical significance, the procedure of pre-staining fixation of a biological object is expected to preserve the structure of cellular organelles and extracellular tissue components. Specifically, for the immunohistochemical detection of proteins, it is important to retain their antigenic properties during and after fixation. Thus, the primary quality of the selected fixative, intended for the subsequent immunohistochemical study, should be the ability to ensure the preservation of biological tissue without affecting (or minimally affecting) the antigenic properties of macromolecules.

Among the qualities of any histological fixatives are also the absence of toxicity, simplicity of preparation and a low cost of the components. At present, there is an abundance of methods and technologies for fixation of biological material; those differ between different immunohistochemical protocols and may cause different, sometimes unidentified, artifacts. A reasonable question arises, whether these specific methods of fixation are good enough to carry out an adequate and informative immunocytochemical test. The purpose of this review is to compare the classical and novel technologies of sample processing for immunohistochemistry.

Aldehydes. The most common fixative used in histological and electron microscopic protocols are

Corresponding author: Igor P. Grigorev, e-mail: ipg-iem@yandex.ru 
aldehydes, usually formic or glutaric, often called formaldehyde and glutaraldehyde, respectively.

Formaldehyde is a water-soluble gas. The concentration of a saturated solution of formaldehyde in water is $40 \%$ (by volume) or $37 \%$ (by weight). Aqueous solution of formaldehyde is called formalin, its saturated solution is considered to be $100 \%$; and $10 \%$ formalin is used to fix biological tissue [1]. Such a solution contains $4 \%$ formaldehyde. In solution, formaldehyde molecules interact with each other over time, forming polymers (with a degree of polymerization of up to 100 units); that is called paraformaldehyde. In concentrated formaldehyde solutions, the polymers gradually form a white precipitate, and its amount depends on the storage conditions. To reduce the polymerization of formaldehyde, manufacturers add $10 \%$ methanol to $40 \%$ solution of formaldehyde.

In formalin solutions, formaldehyde molecules interact with each other not only during the polymerization reaction, but also in the Cannizzaro reaction, where one formaldehyde molecule is reduced to methanol and the other is oxidized to formic acid [2, 3]. As a result, formic acid gradually accumulates in formalin during storage, which causes acidification of the solution and can adversely affect the quality of fixation. Because of this, to standardize the fixation procedure, it is preferable to use fresh formalin, which can be prepared directly in the laboratory from a commercial Paraform preparation by dissolving it in hot water at a ratio of $4 \mathrm{~g}$ of dry paraformaldehyde to $100 \mathrm{ml}$ of distilled water.

Formalin fixes tissues by chemical transformation of macromolecules, forming intra- and intermolecular methylene crosslinks between amino acids (both free and those of proteins), between nucleic acids, and also between amino acids and nucleic acids [2, 4-9]. The crosslinks can be formed only in the presence of uncharged amino groups that exist only at neutral $\mathrm{pH}$ values. Therefore, to use formalin as a fixative, it is necessary to prepare it with a buffered solution, usually with $0.1 \mathrm{M}$ phosphate buffer $(\mathrm{pH} 7.2-7.4)$. The resulting neutral buffered $10 \%$ formalin is used for decades as the standard for tissue fixation in pathology. Such fixation allows for obtaining high-quality histological preparations that completely satisfy the requirements of histological and pathological analysis.

Glutaraldehyde fixes the tissue similarly to formaldehyde, forming inter- and intramolecular crosslinks in proteins and nucleic acids, but each molecule of glutaraldehyde contains not one but two aldehyde groups. Therefore, its ability to interact with macromolecules in biological tissue is higher, and its effect on the protein structure is greater than that of formalin [10-12]. The intermolecular crosslinks formed by glutaraldehyde between polypeptide molecules are so strong that glutaraldehyde is used even in cardiovascular surgery to crosslink collagen fibers and enhance their mechanical strength [13]. During storage, molecules of glutaraldehyde form oligomers [11], which penetrate the tissue depth more slowly than monomers. Therefore, for fixation with glutaraldehyde, only small pieces of tissues should be used. After fixation, a significant amount of unreacted glutaraldehyde molecules may be retained in the sample; those are capable of non-specific binding of antibodies as well as histological and histochemical dyes, which necessitates the use of special procedures for removing excess glutaraldehyde before starting the immunohistochemical staining [2].

It is important to note that the tissue fixed with glutaraldehyde has marked spontaneous fluorescence due to the reaction of glutaraldehyde with certain amines, lipids and proteins, especially collagen [11, 14]. This phenomenon significantly limits the use of glutaraldehyde with the material intended for further fluorescence measurements or laser confocal microscopy; in such cases, additional procedures to block autofluorescence are required [14-20]. It should be noted that even after fixation in formalin, some tissue autofluorescence occurs, especially in a material left in the fixing solution for a long time; the signal though is much lower than that after treatment with glutaraldehyde [21-25].

A considerable shortcoming of glutaraldehyde fixation is that due to the increased crosslinking of protein molecules, a dense tissue is formed; this dense tissue is hardly permeable to molten paraffin, which makes paraffin impregnation more difficult. In addition, this fixation procedure causes excessive compaction of the tissue blocks and complicates the preparation of standard paraffin sections. The above factors significantly reduce the value of using glutaraldehyde for fixation with subsequent paraffin embedment of histological objects [2]. Because of that, glutaraldehyde is normally used to fix small-size samples for further examination by electron microscopy or electron immunocytochemistry; in such protocols, the samples are encapsulated in special polymerizable resins capable of penetrating the glutaraldehyde-fixed tissue [16, 26-32].

The modification of the tertiary and quaternary structure of proteins by formalin or glutaraldehyde $[4,10$, 11, 33-41] leads to changes in the antigenic properties of these proteins. Specifically, part of the epitopes become masked, which prevents them from interacting with the added antibodies and thus interferes with their immunohistochemical detection [42-46]. Although there is evidence that, not only during fixation but also at other stages of sample processing, the masking of antigens takes place [47-49], fixation is considered the main factor that negatively impacts the detection of tissue antigens [46]; the degree of this impact depends on the concentration of the fixative [50].

The use of sections prepared from unfixed frozen samples allows for a more effective implementation of immunohistochemistry methods; however, preservation of cell structures without fixation remains poor.

The formation of intermolecular crosslinks after 
fixation with formalin is a reversible process, at least in part, and the epitopes of detectable antigens can be unmasked with proteolytic enzymes or an elevated temperature [51-53]. For the enzymatic unmasking, trypsin, chymotrypsin, pepsin, pronase, proteinase $\mathrm{K}$, and other proteases are used. For the heat induced epitope retrieval, the samples placed into various buffer media are subjected to heating in a microwave oven, microwave heating under high pressure, autoclaving, boiling under pressure, steam heating, or water bath heating $[51,54-56]$. The acidity $(\mathrm{pH})$ of the buffer medium for heat induced epitope retrieval is important [4]. The optimal method of thermal or enzymatic unmasking is determined experimentally for each specific antigen [51,57]. In a number of cases, after the heat induced epitope retrieval an additional blockage may be needed to suppress non-specific and background reactions in the sample under study [52].

Since recently, another aldehyde fixative, glyoxal, has been used for immunohistochemical studies [58]. This simple dialdehyde has an advantage over formaldehyde - it is able to fix tissues faster and with less intermolecular crosslinks between proteins. Thus, its interference with polypeptides and their antigenic structure is less than that of formaldehyde, which allows for running immunohistochemical staining without prior unmasking [58, 59]. Glyoxal, however, reacts with arginine residues in polypeptide chains to form imidazole; as a result, the arginine-rich antigens may be distorted, which prevents their immunohistochemical detection.

Dehydrating fixatives. In addition to aldehydes, an important group of fixatives is represented by dehydrating (coagulating) agents. They include ethanol and methanol, as well as acetone. These substances have long been used to fix biological material alone or, more often, in various combinations with other chemicals. Alcohols and acetone are capable of dehydrating the tissue; the replacement of water molecules with alcohol or acetone destroys hydrophobic and hydrogen bonds, leading to modification of the tertiary structure, protein denaturation and a change in the antigenic structure [35, 60]. However, the decrease in the protein antigenicity after using of dehydrating fixatives is less pronounced than after fixation in formalin [61]. Therefore, even a material fixed in formalin was proposed to be placed in ethanol or a mixture of ethanol-acetic acid (2:1) before the subsequent use for immunohistochemistry [33, 62, 63]. Along with that, a poor preservation quality of cellular structures, especially membranes, and a significant deterioration in detectability of some proteins was found in monolayer cell culture after fixation in acetone or methanol as compared to formalin or glutaraldehyde [64].

It should be noted that using coagulating fixatives may negatively affect, first of all, the detection of lowmolecular compounds and haptens; those can escape into the solution since they are not strongly bound to the cell compartments. In contrast, high-molecular compounds not bound to cell membranes (for example, intermediate filament proteins) are well identified after treatment by coagulating fixatives [65].

Other fixatives. In addition to the above major fixatives, there are a large number of fixing compositions that incorporate the major fixing agents at different proportions with the addition of other components. In the histological techniques, such fixatives as the Bouin's reagent (mixture of a saturated aqueous solution of picric acid, formalin and glacial acetic acid at a ratio of 15:5:1) are widely used. Among other examples: the Carnoy's solution (absolute alcohol, chloroform and glacial acetic acid, 6:3:1); methacarnoy fixative, or methacarn, in which ethyl alcohol is replaced by methyl (methanol, chloroform and glacial acetic acid, 6:3:1); alcohol-formol $\left(96^{\circ}\right.$ ethanol and formalin, 9:1); alcoholformaldehyde-acetic acid, 85:10:5); periodate-lysineparaformaldehyde-PLP (3\% paraformaldehyde, $75 \mathrm{mM}$ L-lysine, $10 \mathrm{mM} \mathrm{NalO}_{4}$ in $0.1 \mathrm{M}$ phosphate buffer), etc. In addition, solutions of heavy metal salts - mercury, chromium or osmium (Zenker's fixative, chromic acid and potassium dichromate, osmium tetroxide) are used for fixation.

Some of these fixatives have been tested for preparation of sample for immunohistochemical staining. For example, it was noted that after fixation in the Carnoy's solution, many antigens can be well detected, even better than after the standard fixation in neutral formalin [66-69]. Fixation with methacarn also allowed for visualization of certain epitopes better than after fixation with formalin [70]. The comparison of fixation with acetone, ethanol, neutral formalin and neutral formalin + calcium chloride produced mixed results. Thus, different antigens were identifiable better or worse after the treatment with different fixative reagents; according to some authors [71, 72], after fixation with neutral formalin most of the sought antigens could be visualized upon immunohistochemical staining. However, other studies [60,73] showed poor detectability of antigens after fixation in formalin as compared with other tested fixatives: ethanol, methanol, acetone, the Bouin's reagent, alcohol-formol, or zinc-formalin. The detection of epitopes after prolonged fixation in neutral formalin was particularly poor [7, 74, 75].

The PLP fixative was shown to preserve the intact antigenic structure much better than formalin; for a number of proteins fixed with PLP, there is no need in the subsequent antigens unmasking [61]. However, when the biological sample preservation was compared between different fixative agents, PLP was found to cause the strongest compression of tissues upon fixation. In this respect, formalin was less aggressive, and the zinc-containing fixatives were the least compressive fixatives [76]. There is a report that the antigens of invertebrate tissue remained well-preserved after fixation in a mixture of uranyl acetate, trehalose, and methanol [77]. 
Regarding the toxicity of heavy metals, there were attempts to avoid their use for fixation. As it was reported, mercury chloride could be replaced with zinc salts (chloride, sulfate) so the resulting reagent contained zinc ions as the only fixing agent [78]. Although the mechanism of fixation by zinc ions is not fully understood, biological samples fixed with zinc showed a good preservation quality of cells and extracellular material; notably, the zinc-containing fixative was advantageous for the preservation of antigens in comparison with neutral formalin [78-82] or periodatelysine-paraformaldehyde [83]. Nevertheless, as noted by the authors, aqueous solutions of zinc salts penetrate the depth of a fixed sample not fast enough, which can cause an uneven immunoreactivity of antigens located on the surface or in deep layers of the tissue.

In the Laboratory of Morphology at the Institute of Experimental Medicine (Saint Petersburg), a new zinc-containing combination fixative - zinc-ethanolformaldehyde (1 $\mathrm{g}$ of zinc chloride in $96 \%$ ethanol and concentrated formalin, 9:1) — was developed [84]; that reagent demonstrated good preservation of the brain tissue and internal organs of humans and laboratory animals [85, 86]. Immunohistochemical study of nervous tissue (definitive and embryonic) and peripheral organs fixed in zinc-ethanol-formaldehyde allowed for detecting a large number of proteins: calbindin, calretinin, choline acetyltransferase, glutamate decarboxylase, glial fibrillary acidic protein, Iba-1 and NeuN proteins, neuronspecific enolase, synaptophysin, tyrosine hydroxylase, alpha-tubulin, vimentin, nestin and others [87-98]. In addition, immunohistochemical visualization of some antigens did not require heat induced epitope retrieval.

Available commercial offers. In a search for fixatives that would ensure good preservation of every morphological detail and minimally change the antigens, commercial companies offer new types of fixing solutions for immunohistochemical analysis. Among them, CytoSkelFix, F-Solv, FineFIX, Sensofix, RCL2, LN-FIX, FineFIX, UMFIX, Glyo-Fixx, FineFIX, HOPE, NEO-FIX, Cell-Block, ExcellPlus, Greenfix, UPM, CyMol, etc. [73, 99-109]. These trade names often conceal combinations of well-known aldehyde or alcohol fixatives, sometimes added with original admixtures. For example, the UPM fixative is a mixture of ethanol, methanol, 2-propanol, and formalin; CyMol - ethanol, methanol, and 2-propanol; Greenfix - ethanol and ethanediol. However, the precise composition of these fixatives is not disclosed to the public; therefore, it is difficult to assess the effects of individual components of a commercial product on the preservation and antigenic properties of biological samples.

Fixation of biological material for electron microscopic immunocytochemistry requires special conditions. Usually the fixation is made with glutaraldehyde, osmium tetroxide or uranyl acetate; the latter two are also used for contrasting the sample, which is needed for viewing it by means of an electron microscope.
For a combined light and electron microscopy immunocytochemical examination, a mixture of glutaraldehyde and paraform - the so-called Karnovsky's fixative and its variants - is used [10, 110-112]. Acrolein (acrylic acid aldehyde) is also used thanks to its relatively mild masking impact on the tissue antigens; however, acrolein is extremely toxic, therefore it is used rarely or in a combination with glutaraldehyde or formaldehyde [10].

Osmium tetroxide has been shown to mask antigens [10, 113, 114], which makes its use in immunocytochemistry problematic. Due to this, tannic acid has been suggested to replace osmium; tannic acid produces a well-contrasted material for electron microscopy and also provides for the detection of antigens at the ultrastructural level [115-117]. Another option is to use glutaraldehyde alone and dissolve it in a buffer with a balanced ionic composition [118]. Good preservation of the ultrastructure and the antigens was achieved after fixing the material in periodate-lysineparaformaldehyde [119].

\section{Conclusion}

According to the literature, over the recent 25 years of immunohistochemical studies, important improvements in the techniques of biological fixation have been achieved. Yet, none of the fixatives known to date has an ideal combination of properties that enables to obtain high-quality histological preparations and that does not interfere with identification of any antigens in the subsequent immunostaining. The only conclusion from this review is that the optimal fixation protocol should be selected or developed for any specific protein or antibody, considering the experience of others with related proteins. It is not advisable to focus on commercial fixatives with unknown compositions, since their production may be stopped one day for the commercial or technical reasons, and the researcher may be unable to accurately reproduce the conditions required for successful fixation.

Financial support. The work was funded by the State-sponsored grant No.007-01354-17-00 (code: 0557-2016-0017).

Conflict of interest. There are no conflicts of interests related to this study.

\section{References}

1. Korzhevskii D.E. Fiksatsiya materiala dlya gistologicheskogo issledovaniya. $\mathrm{V}$ kn.: Morfologicheskaya diagnostika: podgotovka materiala dlya morfologicheskogo issledovaniya $i$ elektronnoy mikroskopii [Fixation of material for histological research. In: Morphological diagnostics: preparing the material for morphological research and electron microscopy]. Pod red. Korzhevskogo D.E. [Korzhevskii D.E. (editor)]. Saint Petersburg; 2013; p. 10-25.

2. Kiernan J.A. Formaldehyde, formalin, paraformaldehyde 
and glutaraldehyde: what they are and what they do. Micros Today 2000; 8(01): 8-13, https://doi.org/10.1017/ s1551929500057060.

3. Walker J.F. Formaldehyde. New York: Reinhold; 1964.

4. Dapson R.W. Macromolecular changes caused by formalin fixation and antigen retrieval. Biotech Histochem 2007; 82(3): 133-140, https://doi.org/10.1080/ 10520290701567916.

5. Helander K.G. Kinetic studies of formaldehyde binding in tissue. Biotech Histochem 1994; 69(3): 177-179, https://doi. org/10.3109/10520299409106282.

6. Jamur M.C., Oliver C. Cell fixatives for immunostaining. Methods Mol Biol 2010; 588: 55-61, https://doi. org/10.1007/978-1-59745-324-0_8.

7. Leong A.S., Gilham P.N. The effects of progressive formaldehyde fixation on the preservation of tissue antigens. Pathology 1989; 21(4): 266-268, https://doi. org/10.3109/00313028909061071.

8. Masuda N., Ohnishi T., Kawamoto S., Monden M., Okubo K. Analysis of chemical modification of RNA from formalin-fixed samples and optimization of molecular biology applications for such samples. Nucleic Acids Res 1999; 27(22): 4436-4443, https://doi.org/10.1093/nar/27.22.4436.

9. Puchtler H., Meloan S.N. On the chemistry of formaldehyde fixation and its effects on immunohistochemical reactions. Histochemistry 1985; 82(3): 201-204, https://doi. org/10.1007/bf00501395.

10. Griffiths G. Fine structure immunocytochemistry. Springer Berlin Heidelberg; 1993, https://doi.org/10.1007/9783-642-77095-1.

11. Hopwood D. Theoretical and practical aspects of glutaraldehyde fixation. In: Fixation in histochemistry. Stoward P.J. (editor). Springer US; 1973; p. 47-83, https://doi. org/10.1007/978-1-4899-3260-0_2.

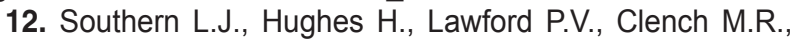
Manning N.J. Glutaraldehyde-induced cross-links: a study of model compounds and commercial bioprosthetic valves. $J$ Heart Valve Dis 2000; 9(2): 241-249.

13. Jang W., Choi S., Kim S.H., Yoon E., Lim H.G., Kim Y.J. A comparative study on mechanical and biochemical properties of bovine pericardium after single or double crosslinking treatment. Korean Circ J 2012; 42(3): 154-163, https://doi. org/10.4070/kcj.2012.42.3.154.

14. Werkmeister J.A., Tebb T.A., Peters D.E., Ramshaw J.A. The use of quenching agents to enable immunofluorescent examination of collagen-based biomaterials showing glutaraldehyde-derived autofluorescence. Clinical Materials 1990; 6(1): 13-20, https://doi.org/10.1016/02676605(90)90040-3.

15. Callis G. Glutaraldehyde-induced autofluorescence. Biotech Histochem 2010; 85(4): 269-270, https://doi. org/10.3109/10520290903472415.

16. Hayat M.A. Principles and techniques of electron microscopy: biological applications. Cambridge: Cambridge University Press, 2000.

17. Kiernan J.A. Histological and histochemical methods: theory and practice. Oxford: Butterworth-Heinemann; 1999.

18. Lee K., Choi S., Yang C., Wu H.C., Yu J. Autofluorescence generation and elimination: a lesson from glutaraldehyde. Chem Commun (Camb) 2013; 49(29): 30283030, https://doi.org/10.1039/c3cc40799c.

19. Ruzin S.E. Plant microtechnique and microscopy. Oxford, New York: Oxford University Press; 1999.
20. Schelkle K.M., Schmid C., Yserentant K., Bender M., Wacker I., Petzoldt M., Hamburger M., Herten D.P., Wombacher R., Schröder R.R., Bunz U.H. Cell fixation by light-triggered release of glutaraldehyde. Angew Chem Int Ed Engl 2017; 56(17): 4724-4728, https://doi.org/10.1002/ ange.201612112.

21. Constantinou P., Dacosta R.S., Wilson B.C. Extending immunofluorescence detection limits in whole paraffinembedded formalin fixed tissues using hyperspectral confocal fluorescence imaging. J Microsc 2009; 234(2): 137-146, https://doi.org/10.1111/j.1365-2818.2009.03155.x.

22. Del Castillo P., Llorente A.R., Stockert J.C. Influence of fixation, exciting light and section thickness on the primary fluorescence of samples for microfluorometric analysis. Basic Appl Histochem 1989; 33(3): 251-257.

23. Kajimura J., Ito R., Manley N.R., Hale L.P. Optimization of single- and dual-color immunofluorescence protocols for formalin-fixed, paraffin-embedded archival tissues J Histochem Cytochem 2016; 64(2): 112-124, https://doi. org/10.1369/0022155415610792.

24. Robertson D., Isacke C.M. Multiple immunofluorescence labeling of formalin-fixed paraffin-embedded tissue. Methods Mol Biol 2011; 724: 69-77, https://doi.org/10.1007/978-161779-055-3_4.

25. Suetterlin R., Baschong W., Laeng R.H. Immunofluorescence and confocal laser scanning microscopy of chronic myeloproliferative disorders on archival formaldehyde-fixed bone marrow. J Histochem Cytochem 2004; 52(3): 347-354, https://doi.org/10. 1177/002215540405200305.

26. Galkina M.V., Snopova L.B., Prodanets N.N., Lapshin R.D., Belousova I.I., Abrosimov D.A., Bugrova M.L. Atrial and brain natriuretic peptides of secretory cardiomyocytes in salt loading in experiment. Sovremennye tehnologii $v$ medicine 2016; 8(3): 49-55, https://doi. org/10.17691/stm2016.8.3.05.

27. Grigor'ev I.P. Ultrastructural reorganizations in the rat cerebral cortex after injection of ascorbic acid into the ventricular fluid. Neurosci Behav Physiol 1989; 19(6): 529 534, https://doi.org/10.1007/bf01181871.

28. Mrini A., Moukhles H., Jacomy H., Bosler O., Doucet G. Efficient immunodetection of various protein antigens in glutaraldehyde-fixed brain tissue. J Histochem Cytochem 1995; 43(12): 1285-1291, https://doi.org/10.1177/43.12.8537644.

29. Otellin V.A., Neokesariiskii A.A., Korzhevskii D.E. Changes in the structure of the nucleus of neocortical neurons during deficiency of serotonin and catecholamines. Tsitologiia 1998; 40(4): 256-259.

30. Bilinski S.M., Jaglarz M.K., Dougherty M.T., Kloc M. Electron microscopy, immunostaining, cytoskeleton visualization, in situ hybridization, and three-dimensional reconstruction of Xenopus oocytes. Methods 2010; 51(1): 1119, https://doi.org/10.1016/j.ymeth.2009.12.003.

31. De Paul A.L., Mukdsi J.H., Petiti J.P., Gutiérrez S., Quintar A.A., Maldonado C.A., Torres A.I. Immunoelectron microscopy: a reliable tool for the analysis of cellular processes. Applications of Immunocytochemistry 2012, https:// doi.org/10.5772/33108.

32. Winey M., Meehl J.B., O'Toole E.T., Giddings T.H. Jr. Conventional transmission electron microscopy. Mol Biol Cell 2014; 25(3): 319-323, https://doi.org/10.1091/mbc.e1212-0863.

33. Baum H.P., Reichrath J., Theobald A., Schock G. 
Fixation requirements for the immunohistochemical reactivity of PCNA antibody PC10 on cryostat sections. Histochem J 1994; 26(12): 929-933, https://doi.org/10.1007/bf00174008.

34. D'Amico F., Skarmoutsou E., Stivala F. State of the art in antigen retrieval for immunohistochemistry. J Immunol Methods 2009; 341 (1-2): 1-18, https://doi.org/10.1016/j. jim.2008.11.007.

35. Eltoum I., Fredenburgh J., Grizzle W.E. Advanced concepts in fixation: 1. Effects of fixation on immunohistochemistry, reversibility of fixation and recovery of proteins, nucleic acids, and other molecules from fixed and processed tissues. 2. Developmental methods of fixation. J Histotechnol 2001; 24(3): 201-210, https://doi.org/10.1179/ his.2001.24.3.201.

36. Mason J.T., O'Leary T.J. Effects of formaldehyde fixation on protein secondary structure: a calorimetric and infrared spectroscopic investigation. J Histochem Cytochem 1991; 39(2): 225-229, https://doi.org/10.1177/39.2.1987266.

37. Meyer W., Hornickel N. Tissue fixation - the most underestimated methodical feature of immunohistochemistry. In: Méndez-Vilas A., Díaz J. (editors). Microscopy: science, technology, applications and education. Vol. 2. Formatex. Microscopy Series. Badajoz: Formatex Research Center; 2010; p. 953-959.

38. Polak J.M., van Noorden S. Introduction to immunocytochemistry. Oxford: BIOS Scientific Publishers; 2003.

39. Shi S.R., Shi Y., Taylor C.R. Antigen retrieval immunohistochemistry: review and future prospects in research and diagnosis over two decades. J Histochem Cytochem 2011; 59(1): 13-32, https://doi.org/10.1369/jhc.2010.957191.

40. Vincek V., Nassiri M., Nadji M., Morales A.R. A tissue fixative that protects macromolecules (DNA, RNA, and protein) and histomorphology in clinical samples. Lab Invest 2003; 83(10): 1427-1435, https://doi.org/10.1097/01. lab.0000090154.55436.d1.

41. Wine Y., Cohen-Hadar N., Freeman A., Frolow F. Elucidation of the mechanism and end products of glutaraldehyde crosslinking reaction by $X$-ray structure analysis. Biotechnol Bioeng 2007; 98(3): 711-718, https://doi. org/10.1002/bit.21459.

42. De Marzo A.M., Fedor H.H., Gage W.R., Rubin M.A. Inadequate formalin fixation decreases reliability of p27 immunohistochemical staining: probing optimal fixation time using high-density tissue microarrays. Hum Pathol 2002; 33(7): 756-760, https://doi.org/10.1053/hupa.2002.126187.

43. Fritschy J.M. Is my antibody-staining specific? How to deal with pitfalls of immunohistochemistry. Eur $\mathrm{J}$ Neurosci 2008; 28(12): 2365-2370, https://doi.org/10.1111/j.14609568.2008.06552.x.

44. Oyama T., Ishikawa Y., Hayashi M., Arihiro K., Horiguchi J. The effects of fixation, processing and evaluation criteria on immunohistochemical detection of hormone receptors in breast cancer. Breast Cancer 2007; 14(2): 182188, https://doi.org/10.2325/jbcs.976.

45. Ramos-Vara J.A. Technical aspects of immunohistochemistry. Vet Pathol 2005; 42(4): 405-426, https://doi.org/10.1354/vp.42-4-405.

46. Watanabe J., Asaka Y., Kanamura S. Relationship between immunostaining intensity and antigen content in sections. J Histochem Cytochem 1996; 44(12): 1451-1458, https://doi.org/10.1177/44.12.8985137.

47. Grizzle W.E., Stockard C.R., Billings P.E. The effects of tissue processing variables other than fixation on histochemical staining and immunohistochemical detection of antigens. J Histotechnol 2001; 24(3): 213-219, https://doi.org/10.1179/ his.2001.24.3.213.

48. Hayat M.A. Microscopy, immunohistochemistry, and antigen retrieval methods: for light and electron microscopy. Springer US; 2002, https://doi.org/10.1007/b112626.

49. Otali D., Stockard C.R., Oelschlager D.K., Wan W., Manne U., Watts S.A., Grizzle W.E. Combined effects of formalin fixation and tissue processing on immunorecognition. Biotech Histochem 2009; 84(5): 223-247, https://doi. org/10.3109/10520290903039094.

50. Muñoz de Toro de Luque M., Luque E.H. Effect of microwave pretreatment on proliferating cell nuclear antigen (PCNA) immunolocalization in paraffin sections. $J$ Histotechnol 1995; 18(1): 11-16, https://doi.org/10.1179/his.1995.18.1.11.

51. Korzhevskii D.E., Gilyarov A.V. Proteoliticheskoe i teplovoe demaskirovanie antigenov. $\mathrm{V}$ kn.: Teoreticheskie osnovy i prakticheskoe primenenie metodov immunogistokhimi [Proteolytic and heat retrieval of antigens. In: Theoretical bases and practical application of immunohistochemical methods]. Pod red. D.E. Korzhevskogo [Korzhevskii D.E. (editor)]. Saint Petersburg; 2012; p. 30-35.

52. Korzhevskii D.E., lumkina E.A. Application of methods of heat retrieval of antigens in paraffin sections of rat brain. Morfologiia 2005; 127(2): 76-77.

53. Leong T.Y., Leong A.S. How does antigen retrieval work? Adv Anat Pathol 2007; 14(2): 129-131, https://doi. org/10.1097/pap.0b013e31803250c7.

54. Boenisch T. Heat-induced antigen retrieval: what are we retrieving? J Histochem Cytochem 2006; 54(9): 961-964, https://doi.org/10.1369/jhc.6p6945.2006.

55. Shi S.-R., Key M.E., Kalra K.L. Antigen retrieval in formalin-fixed, paraffin-embedded tissue: an enhancement method for immunohistochemical staining based on microwave oven heating of tissue sections. J Histochem Cytochem 1991; 39(6): 741-748, https://doi.org/10.1177/39.6.1709656.

56. Shi S.-R., Cote R.J., Taylor C.R. Antigen retrieval techniques: current perspectives. J Histochem Cytochem 2001; 49(8): 931-937, https://doi.org/10. 1177/002215540104900801.

57. Gill S.K., Ishak M., Rylett R.J. Exposure of nuclear antigens in formalin-fixed, paraffin-embedded necropsy human spinal cord tissue: detection of NeuN. J Neurosci Methods 2005; 148(1): 26-35, https://doi.org/10.1016/j. jneumeth.2005.03.008.

58. Dapson R.W. Glyoxal fixation: how it works and why it only occasionally needs antigen retrieval. Biotech Histochem 2007; 82(3): 161-166, https://doi. org/10.1080/10520290701488113.

59. Dapson R.W., Feldman A.T., Wolfe D. Glyoxal fixation and its relationship to immunohistochemistry. J Histotechnol 2006; 29(2): 65-76, https://doi.org/10.1080/01478885.2006.11 800879.

60. Arnold M.M., Srivastava S., Fredenburgh J., Stockard C.R., Myers R.B., Grizzle W.E. Effects of fixation and tissue processing on immunohistochemical demonstration of specific antigens. Biotech Histochem 1996; 71(5): 224-230, https://doi.org/10.3109/10520299609117164.

61. Suzuki M., Katsuyama K., Adachi K., Ogawa Y., Yorozu K., Fujii E., Misawa Y., Sugimoto T. Combination of fixation using PLP fixative and embedding in paraffin by the AMeX method is useful for histochemical studies in 
assessment of immunotoxicity. J Toxicol Sci 2002; 27(3): 165172, https://doi.org/10.2131/jts.27.165.

62. Otali D., He Q., Stockard C.R., Grizzle W.E. Preservation of immunorecognition by transferring cells from $10 \%$ neutral buffered formalin to $70 \%$ ethanol. Biotech Histochem 2013; 88(3-4): 170-180, https://doi.org/10.3109/10 520295.2012.754496.

63. Otali D., He Q., Grizzle W.E. The effect of antigen retrieval on cells fixed in $10 \%$ neutral buffered formalin followed by transfer to $70 \%$ ethanol. PLoS One 2013; 8(12): e82405, https://doi.org/10.1371/journal.pone.0082405.

64. Hoetelmans R.W., Prins F.A., Cornelese-ten Velde I., van der Meer J., van de Velde C.J., van Dierendonck J.H. Effects of acetone, methanol, or paraformaldehyde on cellular structure, visualized by reflection contrast microscopy and transmission and scanning electron microscopy. Appl Immunohistochem Mol Morphol 2001; 9(4): 346-351, https:// doi.org/10.1097/00129039-200112000-00010.

65. Korzhevskii D.E., Lentsman M.V., Kirik O.V., Otellin V.A. Vimentin-immunopositive cells in the rat telencephalon after experimental ischemic stroke. Neurosci Behav Physiol 2008; 38(8): 845-848, https://doi.org/10.1007/s11055-008-9061-y.

66. Giaccone G., Canciani B., Puoti G., Rossi G., Goffredo D., lussich S., Fociani P., Tagliavini F., Bugiani O. Creutzfeldt-Jakob disease: Carnoy's fixative improves the immunohistochemistry of the proteinase K-resistant prion protein. Brain Pathol 2000; 10(1): 31-37, https://doi. org/10.1111/j.1750-3639.2000.tb00240.x.

67. Pereira M.A., Dias A.R., Faraj S.F., Cirqueira Cdos S., Tomitao M.T., Nahas S.C., Ribeiro U. Jr., de Mello E.S Carnoy's solution is an adequate tissue fixative for routine surgical pathology, preserving cell morphology and molecular integrity. Histopathology 2015; 66(3): 388-397, https://doi. org/10.1111/his.12532.

68. Shetye J.D., Scheynius A., Mellstedt H.T., Biberfeld P. Retrieval of leukocyte antigens in paraffin-embedded rat tissues. J Histochem Cytochem 1996; 44(7): 767-776, https:// doi.org/10.1177/44.7.8675998.

69. Yoneyama M., Kitayama T., Taniura H., Yoneda Y. Immersion fixation with Carnoy solution for conventional immunohistochemical detection of particular N-methyl-Daspartate receptor subunits in murine hippocampus. J Neurosci Res 2003; 73(3): 416-426, https://doi.org/10.1002/jnr.10622.

70. James J.D., Hauer-Jensen M. Effects of fixative and fixation time for quantitative computerized image analysis of immunohistochemical staining. J Histotechnol 1999; 22(2): 109-111, https://doi.org/10.1179/his.1999.22.2.109.

71. Bos P.K., van Osch G.J., van der Kwast T., Verwoerd-Verhoef H.L., Verhaar J.A. Fixation-dependent immunolocalization shift and immunoreactivity of intracellular growth factors in cartilage. Histochem J 2000; 32(7): 391-396, https://doi.org/10.1023/a:1004023902080.

72. Shi S.R., Liu C., Pootrakul L., Tang L., Young A., Chen R., Cote R.J., Taylor C.R. Evaluation of the value of frozen tissue section used as "gold standard" for immunohistochemistry. Am J Clin Pathol 2008; 129(3): 358366, https://doi.org/10.1309/7cxuyxt23e5al8kq.

73. Sillevis Smitt P.A., van der Loos C., Vianney de Jong J.M., Troost D. Tissue fixation methods alter the immunohistochemical demonstrability of neurofilament proteins, synaptophysin, and glial fibrillary acidic protein in human cerebellum. Acta Histochem 1993; 95(1): 13-21, https://doi.org/10.1016/s0065-1281(11)80381-8.
74. Eastwood S.L., Burnet P.W., McDonald B., Clinton J., Harrison P.J. Synaptophysin gene expression in human brain: a quantitative in situ hybridization and immunocytochemical study. Neuroscience 1994; 59(4): 881-892, https://doi. org/10.1016/0306-4522(94)90292-5.

75. Webster J.D., Miller M.A., Dusold D., RamosVara J. Effects of prolonged formalin fixation on diagnostic immunohistochemistry in domestic animals. J Histochem Cytochem 2009; 57(8): 753-761, https://doi.org/10.1369/ jhc.2009.953877

76. Wehrl H.F., Bezrukov I., Wiehr S., Lehnhoff M., Fuchs K., Mannheim J.G., Quintanilla-Martinez L., Kohlhofer U. Kneilling M., Pichler B.J., Sauter A.W. Assessment of murine brain tissue shrinkage caused by different histological fixatives using magnetic resonance and computed tomography imaging Histol Histopathol 2015; 30(5): 601-613.

77. Schmidt J., Bodor O., Gohr L., Kunz W. Paramyosin isoforms of Schistosoma mansoni are phosphorylated and localized in a large variety of muscle types. Parasitology 1996; 112(5): 459-467, https://doi.org/10.1017/s0031182000076927.

78. Beckstead J.H. A simple technique for preservation of fixation-sensitive antigens in paraffin-embedded tissues. $J$ Histochem Cytochem 1994; 42(8): 1127-1134, https://doi. org/10.1177/42.8.8027531.

79. Ismail J.A., Poppa V., Kemper L.E., Scatena M., Giachelli C.M., Coffin J.D., Murry C.E. Immunohistologic labeling of murine endothelium. Cardiovasc Pathol 2003; 12(2): 82-90, https://doi.org/10.1016/s1054-8807(02)00166-7.

80. Lynn J.A., Whitaker B.P., Hladik C.L., Robinson R.J., Joie J.B., Stigliano W.W., Carson F.L. Zinc isopropyl alcoholic unbuffered formalin as a postfixative for routine surgical pathology specimens. J Histotechnol 1994; 17(2): 105-109, https://doi.org/10.1179/014788894794710986.

81. Ott S.R. Confocal microscopy in large insect brains: zinc-formaldehyde fixation improves synapsin immunostaining and preservation of morphology in whole-mounts. J Neurosci Methods 2008; 172(2): 220-230, https://doi.org/10.1016/j. jneumeth.2008.04.031.

82. Wester K., Asplund A., Bäckvall H., Micke P., Derveniece A., Hartmane I., Malmström P.U., Pontén F. Zinc-based fixative improves preservation of genomic DNA and proteins in histoprocessing of human tissues. $L a b$ Invest 2003; 83(6): 889-899, https://doi.org/10.1097/01. lab.0000074892.53211.a5.

83. Accart N., Sergi F., Rooke R. Revisiting fixation and embedding techniques for optimal detection of dendritic cell subsets in tissues. J Histochem Cytochem 2014; 62(9): 661671, https://doi.org/10.1369/0022155414539963.

84. Korzhevskii D.E., Grigor'ev I.P., Otellin V.A. Use of zinccontaining dehydrating fixatives for neurohistological studies. Morfologiia 2006; 129(1): 85-86.

85. Korzhevskii D.E., Sukhorukova E.G., Gilerovich E.G. Petrova E.S., Kirik O.V., Grigor'ev I.P. Advantages and disadvantages of zinc-ethanol-formaldehyde as a fixative for immunocytochemical studies and confocal laser microscopy. Neurosci Behav Physiol 2014; 44(5): 542-545, https://doi. org/10.1007/s11055-014-9948-8

86. Korzhevskii D.E., Sukhorukova E.G., Kirik O.V., Grigorev I.P. Immunohistochemical demonstration of specific antigens in the human brain fixed in zinc-ethanolformaldehyde. Eur J Histochem 2015; 59(3): 2530, https://doi. org/10.4081/ejh.2015.2530.

87. Alekseeva O.S., Vetosh A.N., Kostkin V.B., 
Korzhevskiy D.E., Otellin V.A. Heat shock proteins in brain neurons and hypoxic preconditioning. Dokl Biol Sci 2009; 425(1): 98-100, https://doi.org/10.1134/s0012496609020045.

88. Gilerovich E.G., Fedorova E.A., Grigor'ev I.P., Korzhevskii D.E. Morphological basics for reorganization of the rat cerebellar cortex during senescence. J Evol Biochem Physiol 2015; 51(5): 421-427, https://doi.org/10.1134/ s0022093015050087.

89. Grigor'ev I.P., Korzhevskii D.E., Sukhorukova E.G., Gusel'nikova V.V., Kirik O.V. Intranuclear ubiquitinimmunopositive structures in human substantia nigra neurons. Cell and Tissue Biology 2016; 10(1): 29-36, https://doi. org/10.1134/s1990519x16010053.

90. Grigoriev I.P., Vasilenko M.S., Sukhorukova E.G., Korzhevskii D.E. Use of different antibodies to tyrosine hydroxylase to study catecholaminergic systems in the mammalian brain. Neurosci Behav Physiol 2012; 42(2): 210 213, https://doi.org/10.1007/s11055-011-9555-x.

91. Kirik O.V., Korzhevskii D.E. Expression of neural stem cell marker nestin in the kidney of rats and humans. Bull Exp Biol Med 2009; 147(4): 539-541, https://doi.org/10.1007/ s10517-009-0541-z.

92. Kirik O.V., Korzhevskii D.E. Vimentin in ependymal and subventricular proliferative zone cells of rat telencephalon. Bull Exp Biol Med 2013; 154(4): 553-557, https://doi.org/10.1007/ s10517-013-1998-3.

93. Kirik O.V., Grigorev I.P., Alekseeva O.S., Korzhevskii D.E. Three-dimensional organization of the cytoplasmic neuroglobin-immunopositive structures in the rat brainstem neurons. Biochem Moscow Supp/ Ser A 2016; 10(4): 333-337, https://doi.org/10.1134/s1990747816030065.

94. Korzhevskii D.E., Grigor'ev I.P., Kirik O.V., Alekseeva O.S. Neuroglobin distribution in the rat cerebellar Purkinje cells. J Evol Biochem Phys 2015; 51(6): 517-519, https://doi.org/10.1134/s0022093015060095.

95. Korzhevskii D.E., Grigor'ev I.P., Sukhorukova E.G., Gusel'nikova V.V. Immunohistochemical characteristics of the substantia nigra neurons of the human. Zhurnal nevrologii $i$ psikhiatrii im. S.S. Korsakova 2017; 117(4): 50-55, https://doi. org/10.17116/jnevro20171174150-55.

96. Petrova E.S., Isaeva E.N., Korzhevskii D.E. Differentiation of dissociated rat embryonic brain after allotransplantation into damaged nerve. Bull Exp Biol Med 2013; 156(1): 136-138, https://doi.org/10.1007/s10517-0132296-9.

97. Chumasov E.I., Korzhevskii D.E., Petrova E.S., Sapronov N.S., Kuznetsova N.N. Glial reaction of the subventricular zone of the telencephalon of the rat brain on modeling of Alzheimer's disease. Neurosci Behav Physiol 2012; 42(1): 67-71, https://doi.org/10.1007/s11055-011-9535-1.

98. Chumasov E.I., Petrova E.S., Korzhevskii D.E. Distribution and structural organization of the autonomic nervous apparatus in the rat pancreas (an immunohistochemical study). Neurosci Behav Physiol 2012; 42(8): 781-788, https://doi.org/10.1007/s11055-012-9635-6.

99. Benerini Gatta L., Cadei M., Balzarini P., Castriciano S., Paroni R., Verzeletti A., Cortellini V., De Ferrari F., Grigolato P. Application of alternative fixatives to formalin in diagnostic pathology. Eur J Histochem 2012; 56(2): e12, https://doi. org/10.4081/ejh.2012.12.

100. Lassalle S., Hofman V., Marius I., Gavric-Tanga V., Brest P., Havet K., Butori C., Selva E., Santini J., Mograbi B., Hofman P. Assessment of morphology, antigenicity, and nucleic acid integrity for diagnostic thyroid pathology using formalin substitute fixatives. Thyroid 2009; 19(11): 1239-1248, https:// doi.org/10.1089/thy.2009.0095.

101. Moelans C.B., ter Hoeve N., van Ginkel J.W., ten Kate F.J., van Diest P.J. Formaldehyde substitute fixatives. Analysis of macroscopy, morphologic analysis, and immunohistochemical analysis. Am J Clin Pathol 2011; 136(4): 548-556, https://doi.org/10.1309/ajcphh1b0cocbgom.

102. Nadji M., Nassiri M., Vincek V., Kanhoush R., Morales A.R. Immunohistochemistry of tissue prepared by a molecular-friendly fixation and processing system. Appl Immunohistochem Mol Morphol 2005; 13(3): 277-282, https:// doi.org/10.1097/01.pai.0000146544.51771.79.

103. Nykänen M., Kuopio T. Protein and gene expression of estrogen receptor alpha and nuclear morphology of two breast cancer cell lines after different fixation methods. Exp Mol Pathol 2010; 88(2): 265-271, https://doi.org/10.1016/j. yexmp.2009.12.003.

104. Olert J., Wiedorn K.H., Goldmann T., Kuhl H., Mehraein Y., Scherthan H., Niketeghad F., Vollmer E., Müller A.M., Müller-Navia J. HOPE fixation: a novel fixing method and paraffin-embedding technique for human soft tissues. Pathol Res Pract 2001; 197(12): 823-826, https://doi. org/10.1078/0344-0338-00166.

105. Paavilainen L., Edvinsson A., Asplund A., Hober S., Kampf C., Pontén F., Wester K. The impact of tissue fixatives on morphology and antibody-based protein profiling in tissues and cells. J Histochem Cytochem 2010; 58(3): 237-246, https://doi.org/10.1369/jhc.2009.954321.

106. Preusser M., Plumer S., Dirnberger E., Hainfellner J.A., Mannhalter C. Fixation of brain tumor biopsy specimens with RCL2 results in well-preserved histomorphology, immunohistochemistry and nucleic acids. Brain Pathol 2010; 20(6): 1010-1020, https://doi.org/10.1111/ j.1750-3639.2010.00400.x.

107. Robinson R.W., Snyder J.A. An innovative fixative for cytoskeletal components allows high resolution in colocalization studies using immunofluorescence techniques. Histochem Cell Biol 2004; 122(1): 1-5, https://doi.org/10.1007/ s00418-004-0656-2.

108. Vollmer E., Galle J., Lang D.S., Loeschke S., Schultz H., Goldmann T. The HOPE technique opens up a multitude of new possibilities in pathology. Rom $\mathrm{J}$ Morphol Embryol 2006; 47(1): 15-19.

109. Zanini C., Gerbaudo E., Ercole E., Vendramin A., Forni M. Evaluation of two commercial and three home-made fixatives for the substitution of formalin: a formaldehyde-free laboratory is possible. Environ Health 2012; 11: 59, https://doi. org/10.1186/1476-069x-11-59.

110. Hinova-Palova D.V., Landzhov B., Dzhambazova E., Minkov M., Edelstein L., Malinova L., Paloff A., Ovtscharoff W. Neuropeptide $Y$ immunoreactivity in the cat claustrum: a light- and electron-microscopic investigation. J Chem Neuroanat 2014; 61-62: 107-119, https://doi.org/10.1016/j. jchemneu.2014.08.007.

111. Persson S., Havton L.A. Retrogradely transported fluorogold accumulates in lysosomes of neurons and is detectable ultrastructurally using post-embedding immuno-gold methods. J Neurosci Methods 2009; 184(1): 42-47, https://doi. org/10.1016/j.jneumeth.2009.07.017.

112. Watanabe I.S., Dias F.J., Mardegan Issa J.P., dos Santos Haemmerle C.A., Cury D.P., Takada S.H., Sosthenes M.C., Pereira da Silva M.C., Campos L.M., 
Nogueira M.I., lyomasa M.M. Immunohistochemistry and ultrastructural characteristics of nerve endings in the oral mucosa of rat. Microscopy 2013; 62(2): 259-270, https://doi. org/10.1093/jmicro/dfs068.

113. Stirling J.W. Ultrastructural localization of lysozyme in human colon eosinophils using the protein A-gold technique: effects of processing on probe distribution. J Histochem Cytochem 1989; 37(5): 709-714, https://doi. org/10.1177/37.5.2467929.

114. Koga D., Kusumi S., Bochimoto H., Watanabe T., Ushiki T. Correlative light and scanning electron microscopy for observing the three-dimensional ultrastructure of membranous cell organelles in relation to their molecular components. J Histochem Cytochem 2015; 63(12): 968-979, https://doi. org/10.1369/0022155415609099.

115. Berryman M.A. Effects of tannic acid on antigenicity and membrane contrast in ultrastructural immunocytochemistry. J Histochem Cytochem 1992; 40(6): 845-857, https://doi.org/10.1177/40.6.1350287.
116. Phend K.D., Rustioni A., Weinberg R.J. An osmium-free method of epon embedment that preserves both ultrastructure and antigenicity for post-embedding immunocytochemistry. J Histochem Cytochem 1995; 43(3): 283-292, https://doi.org/10.1177/43.3.7532656.

117. Zhong L., Brown J.C., Wells C., Gerges N.Z. Postembedding immunogold labeling of synaptic proteins in hippocampal slice cultures. J Vis Exp 2013; 74: e50273, https://doi.org/10.3791/50273.

118. Heck W.L., Slusarczyk A., Basaraba A.M., Schweitzer L. Subcellular localization of GABA receptors in the central nervous system using post-embedding immunohistochemistry. Brain Res Brain Res Protoc 2002; 9(3): 173-180, https://doi.org/10.1016/s1385-299x(02)00143-5.

119. Kinugasa S., Tojo A., Sakai T., Fujita T. Silverenhanced immunogold scanning electron microscopy using vibratome sections of rat kidneys: detection of albumin filtration and reabsorption. Med Mol Morphol 2010; 43(4): 218-225, https://doi.org/10.1007/s00795-010-0500-9. 